\title{
Front Matter: Volume 8169
}

, "Front Matter: Volume 8169," Proc. SPIE 8169, Optical Fabrication, Testing, and Metrology IV, 816901 (13 October 2011); doi: 10.1117/12.917107

SPIE. Event: SPIE Optical Systems Design, 2011, Marseille, France 


\title{
PROCEEDINGS OF SPIE
}

\section{Optical Fabrication, Testing, and Metrology IV}

\author{
Angela Duparré \\ Roland Geyl \\ Editors
}

7-8 September 2011

Marseille, France

Sponsored by

SPIE

Coorganised by

POPsud - Optitec (France)

Cosponsored by

Communauté Urbaine Marseille Provence Métropole (France)

Ville de Marseille (France)

Cooperating Organisation

Schott AG (Germany)

Published by

SPIE 
The papers included in this volume were part of the technical conference cited on the cover and title page. Papers were selected and subject to review by the editors and conference program committee. Some conference presentations may not be available for publication. The papers published in these proceedings reflect the work and thoughts of the authors and are published herein as submitted. The publisher is not responsible for the validity of the information or for any outcomes resulting from reliance thereon.

Please use the following format to cite material from this book:

Author(s), "Title of Paper," in Optical Fabrication, Testing, and Metrology IV, edited by Angela Duparré, Roland Geyl, Proceedings of SPIE Vol. 8169 (SPIE, Bellingham, WA, 2011) Article CID Number.

ISSN 0277-786X

ISBN 9780819487957

Published by

SPIE

P.O. Box 10, Bellingham, Washington 98227-0010 USA

Telephone +1 3606763290 (Pacific Time) · Fax +1 3606471445

SPIE.org

Copyright (C) 2011, Society of Photo-Optical Instrumentation Engineers

Copying of material in this book for internal or personal use, or for the internal or personal use of specific clients, beyond the fair use provisions granted by the U.S. Copyright Law is authorized by SPIE subject to payment of copying fees. The Transactional Reporting Service base fee for this volume is $\$ 18.00$ per article (or portion thereof), which should be paid directly to the Copyright Clearance Center (CCC), 222 Rosewood Drive, Danvers, MA 01923. Payment may also be made electronically through CCC Online at copyright.com. Other copying for republication, resale, advertising or promotion, or any form of systematic or multiple reproduction of any material in this book is prohibited except with permission in writing from the publisher. The CCC fee code is 0277-786X/11/ \$18.00.

Printed in the United States of America.

Publication of record for individual papers is online in the SPIE Digital Library.

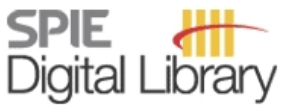

SPIEDigitalLibrary.org

Paper Numbering: Proceedings of SPIE follow an e-First publication model, with papers published first online and then in print and on CD-ROM. Papers are published as they are submitted and meet publication criteria. A unique, consistent, permanent citation identifier (CID) number is assigned to each article at the time of the first publication. Utilization of CIDs allows articles to be fully citable as soon as they are published online, and connects the same identifier to all online, print, and electronic versions of the publication. SPIE uses a six-digit CID article numbering system in which:

- The first four digits correspond to the SPIE volume number.

- The last two digits indicate publication order within the volume using a Base 36 numbering system employing both numerals and letters. These two-number sets start with 00, 01, 02, 03, 04, $05,06,07,08,09,0 A, 0 B \ldots 0 Z$, followed by 10-1Z, 20-2Z, etc.

The CID number appears on each page of the manuscript. The complete citation is used on the first page, and an abbreviated version on subsequent pages. Numbers in the index correspond to the last two digits of the six-digit CID number. 


\section{Contents}

vii Conference Committee

\section{SESSION 1 CONVENTIONAL OPTICS: MANUFACTURING AND TESTING I}

816902 MRF with adjustable pH (Invited Paper) [8169-01]

S. D. Jacobs, Univ. of Rochester (United States)

816903 Stress polishing of E-ELT segment at LAM: full-scale demonstrator status [8169-02] M. Laslandes, N. Rousselet, M. Ferrari, E. Hugot, J. Floriot, S. Vivès, G. Lemaitre, Lab. d'Astrophysique de Marseille (France); J. F. Carré, SESO (France); M. Cayrel, European Southern Observatory (Germany)

816904 Manufacturing and testing of the large lenses for Dark Energy Survey (DES) at SESO [8169-03] D. Fappani, J. Fourez, SESO (France); P. Doel, D. Brooks, Univ. College London (United Kingdom); B. Flaugher, Fermilab Chicago (United States)

816905 TMA optics for HISUI HSS and MSS imagers [8169-04]

R. Geyl, H. Leplan, J. Rodolfo, Sagem SA (France)

816906 Fused silica long-term stability: case studies [8169-05]

M. Vannoni, A. Sordini, G. Molesini, Istituto Nazionale di Ottica, CNR (Italy)

\section{SESSION 2 CONVENTIONAL OPTICS: MANUFACTURING AND TESTING II}

816907 Metrology for an imaging Fourier transform spectrometer working in the far-UV (IFTSUV) [8169-06]

C. Ruiz de Galarreta Fanjul, A. Philippon, J.-C. Vial, Institut d'Astrophysique Spatiale (France); J.-P. Maillard, Institut d'Astrophysique de Paris (France); T. Appourchaux, Institut d'Astrophysique Spatiale (France)

816909 Experimental determination of aberration in lithographic lens by aerial image [8169-09] L. Duan, Shanghai Institute of Optics and Fine Mechanics (China), Graduate School of the Chinese Academy of Sciences (China), and Shanghai Micro Electronics Equipment Co., Ltd. (China); X. Wang, G. Yan, Shanghai Institute of Optics and Fine Mechanics (China); A. Bourov, Shanghai Micro Electronics Equipment Co., Ltd. (China)

\section{SESSION 3 CONVENTIONAL OPTICS: MANUFACTURING AND TESTING III}

8169 OA Wavefront reconstruction and piston measurement using Ronchi test [8169-10] D. H. Penalver, F. Granados-Agustin, D. L. Romero-Antequera, Instituto Nacional de Astrofísica, Óptica y Electrónica (Mexico) 
8169 OC Wafer-level micro-optics: trends in manufacturing, testing, and packaging (Invited Paper) [8169-12]

R. Voelkel, K. J. Weible, M. Eisner, SUSS MicroOptics SA (Switzerland)

8169 OD Fabrication and testing of highly efficient resonance domain diffractive optical elements (Invited Paper) [8169-13]

O. Barlev, M. A. Golub, Tel Aviv Univ. (Israel); A. A. Friesem, D. Mahalu, Weizmann Institute of Science (Israel); M. Nathan, Tel Aviv Univ. (Israel)

\section{SESSION $5 \quad$ MICROOPTICS AND MICROSTRUCTURES II}

8169 OE Method for the characterization of Fresnel lens flux transfer performance [8169-14]

J. C. Martinez Antón, D. Vázquez Moliní, J. Muñoz de Luna, J. A. Gómez Pedrero,

A. Á. Fernández-Balbuena, Univ. Complutense de Madrid (Spain)

8169 OG Manufacturing, testing, and metrology of axi-symmetric circular phase masks for stellar coronagraphy [8169-17]

M. N'Diaye, K. Dohlen, Lab. d'Astrophysique de Marseille, CNRS, Univ. de Provence (France);

S. Tisserand, S. Gautier, Silios Technologies (France); K. El Hadi, G. Moreaux, Lab.

d'Astrophysique de Marseille, CNRS, Univ. de Provence (France); R. Soummer, Space Telescope Science Institute (United States); S. Cuevas, C. Sánchez-Pérez, Univ. Nacional Autónoma de México (Mexico)

$8169 \mathrm{OH} \quad$ Fabrication of bilayer wire grid polarizer using replicated polymer nano grating [8169-18] Y. Han, J. Kim, E. Byeon, S.-M. Kim, Chung-Ang Univ. (Korea, Republic of); Y. Lee,

C. K. Hwangbo, Inha Univ. (Korea, Republic of)

\section{SESSION 6 SCATTERING AND PHOTOMETRY I}

8169 OK Multimodal scattering facilities and modelization tools for a comprehensive investigation of optical coatings (Invited Paper) [8169-21]

M. Zerrad, M. Lequime, C. Amra, Institut Fresnel, CNRS (France)

8169 ON Spectrophotometric bench dedicated to the characterization of micro-patterned optical coatings [8169-24]

S. Sorce, L. Abel-Tiberini, M. Lequime, Institut Fresnel, CNRS (France)

\section{SESSION 7 SCATTERING AND PHOTOMETRY II}

816900 SCPEM-based polarization modulation ellipsometry in the NIR [8169-25]

F. Bammer, Vienna Univ. of Technology (Austria); R. Petkovsek, Univ. of Ljubljana (Slovenia) 
8169 OP Roughness characterization of large EUV mirror optics by laser light scattering [8169-26] M. Trost, Fraunhofer Institute for Applied Optics and Precision Engineering (Germany) and Friedrich-Schiller-Univ. Jena (Germany); S. Schröder, T. Feigl, A. Duparré, Fraunhofer Institute for Applied Optics and Precision Engineering (Germany); A. Tünnermann, Fraunhofer Institute for Applied Optics and Precision Engineering (Germany) and Friedrich-Schiller-Univ. Jena (Germany)

$81690 \mathrm{O}$ 3D features measurement using YieldStar: an angle resolved polarized scatterometer [8169-27]

A.-L. Charley, P. Leray, K. D'havé, S. Cheng, IMEC (Belgium); P. Hinnen, F. Li, P. Vanoppen, M. Dusa, ASML Netherlands B.V. (Netherlands)

8169 OR Impact of surface roughness on the scatter losses and the scattering distribution of surfaces and thin film coatings [8169-28]

S. Schröder, T. Herffurth, A. Duparré, Fraunhofer Institute for Applied Optics and Precision Engineering (Germany); J. E. Harvey, CREOL, The College of Optics and Photonics, Univ. of Central Florida (United States)

SESSION 8 SURFACE PROFILE MEASUREMENT I

8169 OT Isara 400 ultra-precision CMM (Invited Paper) [8169-30]

H. A. M. Spaan, I. Widdershoven, IBS Precision Engineering bv (Netherlands)

8169 OV Non-contact measurement of aspherical and freeform optics with a new confocal tracking profiler [8169-32]

A. Pintó, Sensofar-Tech, S.L. (Spain); F. Laguarta, R. Artigas, C. Cadevall, Technical Univ. of Catalonia (Spain)

8169 OW Phase-shifting fringe projection system using freeform optics [8169-33]

S. Zwick, P. Kühmstedt, G. Notni, Fraunhofer Institute for Applied Optics and Precision Engineering (Germany)

\section{SESSION 9 SURFACE PROFILE MEASUREMENT II}

8169 0X Data handling and representation of freeform surfaces [8169-34]

R. Steinkopf, Fraunhofer Institute for Applied Optics and Precision Engineering (Germany);

L. Dick, JENOPTIK Polymer Systems GmbH (Germany); T. Kopf, A. Gebhardt, S. Risse,

R. Eberhardt, Fraunhofer Institute for Applied Optics and Precision Engineering (Germany)

8169 OY Adaptive two-beam interferometer for testing optical surfaces [8169-35]

A. Miks, J. Novak, P. Novak, Czech Technical Univ. in Prague (Czech Republic)

$81690 Z$ Adaptive null test system using a ferrofluid deformable mirror [8169-36]

D. B. Landry, D. Brousseau, S. Thibault, E. F. Borra, Univ. Laval (Canada)

816910 Optical method for the surface topographic characterization of Fresnel lenses [8169-37]

J. C. Martínez Antón, J. A. Gómez Pedrero, J. Alonso Fernández, J. A. Quiroga, Univ.

Complutense de Madrid (Spain) 
816912 Extremely aspheric surfaces: toward a manufacturing process based on active optics [8169-38]

Z. Challita, E. Hugot, M. Ferrari, D. Le Mignant, S. Vivès, J.-G. Cuby, Lab. d'Astrophysique de Marseille (France)

816913 Two-dimensional thickness measurement of a dielectric thin layer on a metal by use of surface-plasmon-resonance-based ellipsometry [8169-40]

T. Iwata, Y. Wada, K. Nishigaki, Y. Mizutani, Univ. of Tokushima (Japan)

816914 Wavefront instabilities in thin glass mirrors [8169-41]

S. Bouillet, T. Lanternier, E. Lavastre, C. Chappuis, F. Macias, CEA, CESTA (France)

816915 Absolute calibration of three reference flats based on an iterative algorithm: study and implementation [8169-42]

C. Morin, S. Bouillet, CEA, CESTA (France)

Author Index 


\title{
Conference Committee
}

\author{
Symposium Chair
}

Michel Lequime, Institut FRESNEL and Ecole Centrale Marseille (France)

Symposium Cochairs

Andreas Tünnermann, Fraunhofer-Institut für Angewandte Optik und Feinmechanik (Germany)

David M. Williamson, West Malvern (United Kingdom) and Nikon Research Corporation of America (United States)

Conference Chairs

Angela Duparré, Fraunhofer-Institut für Angewandte Optik und Feinmechanik (Germany)

Roland Geyl, Sagem SA (France)

Program Committee

Genevieve M. Chabassier, Commissariat à l'Énergie Atomique (France)

Svetlana Dligatch, Commonwealth Scientific and Industrial Research Organisation (Australia)

Sead Doric, Doric Lenses Inc. (Canada)

James E. Harvey, CREOL, The College of Optics and Photonics, University of Central Florida (United States)

Raymond F. Mercier, Institut d'Optique Graduate School (France)

Manfred Prantl, Alicona Imaging GmbH (Germany)

Alon Regev, Rafael Advanced Defense Systems Ltd. (Israel)

Joanna Schmit, Bruker Corporation (United States)

Theo Tschudi, Technische Universität Darmstadt (Germany)

Reinhard Völkel, SUSS MicroOptics SA (Switzerland)

Lingli Wang, Jos. Schneider Optische Werke GmbH (Germany)

Session Chairs

1 Conventional Optics: Manufacturing and Testing I

Genevieve M. Chabassier, Commissariat à l'Énergie Atomique

(France)

2 Conventional Optics: Manufacturing and Testing II

Roland Geyl, Sagem SA (France) 
3 Conventional Optics: Manufacturing and Testing III

Genevieve M. Chabassier, Commissariat à l'Énergie Atomique (France)

$4 \quad$ Microoptics and Microstructures I

Angela Duparré, Fraunhofer-Institut für Angewandte Optik und Feinmechanik (Germany)

5 Microoptics and Microstructures II

Reinhard Völkel, SUSS MicroOptics SA (Switzerland)

$6 \quad$ Scattering and Photometry I

Angela Duparré, Fraunhofer-Institut für Angewandte Optik und Feinmechanik (Germany)

$7 \quad$ Scattering and Photometry II

Myriam Zerrad, Institut FRESNEL (France)

8 Surface Profile Measurement I

Stephen D. Jacobs, University of Rochester (United States)

9 Surface Profile Measurement II

Roland Geyl, Sagem SA (France) 